\title{
COMMUNITY DIASPORA IN THE MARITIM STRAIT OF MALAKA MALAYSIA : A CASE STUDY OF THE ACEH RUNCIT SHOP
}

\author{
Muhammad Ichsan \\ Master Student of Southeast Asian Studies, \\ Faculty of Humanities, University of Indonesia \\ Correspondence : Isan.mdlife@gmail.com
}

\begin{abstract}
This journal article was written as a study of the Diaspora of the Aceh community in Malaysia. The Tsunami in Aceh 16 years ago has brought big changes to the people, both from the cultural aspects and new ideas that are constantly developing. The earthquake disaster followed by the tsunami caused damage and exacerbated political conflict between GAM and the TNI, which had a major impact on the Acehnese community. This condition made the people of Aceh start thinking about migrating to neighboring countries such as Malaysia because they saw more profitable opportunities. The Diaspora that occurred as a result of the Acehnese who migrated to Malaysia gave birth to a new culture. The presence of the Acehnese in Malaysia is marked by the formation of the Acehnese community and small shops which are the embodiment of the Aceh-Malaysia Diaspora. This study refers to ethnographic principles in the area of the village of Aceh, Yan Kedah. This research is a case study, an exploration and analysis technique in the investigation of a particular social unit. This research was conducted to determine the impact of the presence of the Acehnese diaspora on Malaysia. From the results of the discussion, it was found by researchers that the underlying reason for the Aceh and Malaysian Diaspora was due to the desire of the Acehnese people to leave the conflict zone which threatened the lives of the Acehnese community traders. Then the religious aspects also affect so that it is easy for the Acehnese people to adapt to Malaysia and be able to survive and unite the cultures of Aceh and Malaysia.
\end{abstract}

Keywords: Diaspora, Yan Kedah, Kedai Runcit, Malaysia 


\section{A. Introduction}

The study of diaspora issues continues to increase from time to time. According to (Missbach, 2012), this is true not only because of the increasing growth of the Diaspora community due to waves of migration around the world but also because the role played by the diaspora community is the same in the country of origin and the country they live in. However, according to Wong's and Afrisal's studies, what happened was mainly the life of the Acehnese diaspora community in Malaysia when Aceh was affected by armed conflict and war. This conflict occurred as a result of political fighting between the Free Aceh Movement (GAM) and the Indonesian government (Wong \& Afrisal, 2002). One of the impacts of the Acehnese diaspora in the Malaysian state is the emergence of Kedai Runcit Aceh which has become an icon that is not realized by the people in Malaysia. There are shop names with various company names/trade names plastered at the entrance, but the Aceh shop is still mentioned. The customers of the Aceh shop are not only among Acehnese and Sumatran migrants but are also in demand by the general public in Malaysia, especially the Muslim Malay community. From these reference sources, researchers are interested in studying the impact of the Acehnese and Malaysian ethnic diaspora.

\section{Literature Review}

Here are some literature reviews that support this research journal:

This article highlights how the Acehnese diaspora adapts to the Memorandum of Understanding (MoU), the peace agreement signed between the Indonesian government and the Free Aceh Movement after nearly 30 years of smallscale war in Aceh. Analyzing the diasporic response needs to consider two locations: the host country of residence in the Aceh province and the homeland, where nomads return and become involved in local politics. Spontaneous and temporary returns decreased the Acehnese diaspora significantly in numbers and this decline correlated with the loss of impact on homeland politics. Unlike in times of conflict, the homeland no longer needs their involvement. Most of the remaining aspirants adjust to the loss of meaning by changing their collective activities to suit their new and more limited opportunities. Instead of distance politics, they focus on identity 
politics to maintain their Acehnese abroad. However, at the same time, the process of de-vaporization was accompanied by a subtle wave of political re-vaporization. As the conflict in Aceh was the main reason for the vaporization of the Acehnese people abroad, the end of the conflict now threatens the cohesion of the diaspora. To save not only the idea of togetherness but also the reputation of the diaspora as the spearhead of Acehnese independence, several aspirants continue to dedicate their activities to this separatist goal. Antje Missbach (2011).

According to Bustami (2015), it can be concluded that the relationship between the Acehnese and the Malay community in Malaysia has been going on for quite a long time, especially when Aceh experienced a period of glory under the Kingdom of Aceh Darussalam. When the Kingdom of Aceh began to engage in war with the Kingdom of the Netherlands, many Acehnese migrated to Pulau Pinang with the main aim of trading and carrying out political activities to win Aceh in the war.

Also, during that period, many Acehnese migrated to Kedah. This migration group was led by clerics to save their students from the rage of war. Furthermore, many traders migrated. Therefore, this migration can be said to have two main motives, namely messaging (studying religion) and meuniaga (trading).

The Acehnese community who migrated to Yan then built a village called Kampung Acheh. The ulama who led the migration then built the dayah as a center for religious education activities. They also succeeded in becoming scholars who were respected, both by the Acehnese community and by the local Malay community. Also, there are Acehnese there who triumphed in becoming accomplished traders who were known to have a lot of wealth and love to give. So, this research want to know what impact did the small shop have on the diaspora process that took place between Aceh and Malaysia?. The purpose of this study was to determine the impact caused by the runcit shop on the diaspora process that occurred between Aceh and Malaysia.

\section{Research Objectives}

The following are some of the research objectives described from the research objectives that underlie this journal: 
1. This study aims to understand the background of the social relations between the Acehnese and the Malay peninsula and to explain the influencing factors. Its benefits are as study material in conducting more in-depth research.

2. To know for sure the views of the Acehnese on the Malay Malay Peninsula, towards the country and culture of Aceh.

3. To explore the efforts made by the Acehnese ethnic Malay peninsula in Yan in perpetuating their socio-cultural identity as Acehnese.

4. To analyze the actions taken by the Acehnese in the Malay Peninsula, Yan Kedah's research object was to be accepted as an expert on local communities.

\section{B. Method}

This research is a case study, an exploration and analysis technique in the investigation of a particular social unit. In essence, case studies require deep and intensive exploration. Therefore, usually, only a few incidents can be brought up to become material for investigation in this way (Komaruddin; 1984, p. 41; Afrizal; 2005). The case that the researcher will raise is the materialistic dominant representation of the diaspora.

According to Hana Naufanita, Raden Maisa Yudono, Ani Soetjipto (2018) Diaspora is a term commonly used. Its discursive nature makes the diaspora mean everything, tailored for whoever articulates it. The idea of the Indonesian diaspora has spread since 2012. The diaspora is articulated by non-state actors, expatriate groups. This group changed the state's perception of expatriates from traitors to state assets. State and non-state actors aim to maximize capital through skills, remittances, and investment. This is confirmed in Presidential Decree No. 76 of 2017 concerning Facilities for Indonesian Communities Abroad. We argue that the Indonesian diaspora is a discourse articulated by interest groups and supported by the state to maximize capital. Meanwhile, the diaspora is constantly creating, changing, and maintaining metaphors to redefine the identity of a nation. 
This article analyzes power relations in the discourse of the Indonesian diaspora and also examines the concept of national identity in IR which generally uses a state-centric perspective that sees the state as a unitary and sovereign unitary. According to these references, it is evident that the diaspora that occurs between the Acehnese and the Malaysian state is by popping up popular shops in strategic places in Malaysia.

\section{Result and Discussion}

\section{Overview of Kampung Aceh, Yan Kedah}

The Kedah-Aceh relationship has a unique history and dates back to the 1600s AD. The Acehnese first migrated and settled in several areas in Kedah and eventually formed the Aceh community. Assessment of the role and contribution of the Acehnese people from a social perspective, namely in the religious and intellectual, economic, and political aspects of the country of Kedah and to know for sure the phenomenon of the Acehnese hijrah from the historical aspects and past relations in the country of Kedah. Primary sources are Archib Negara Malaysia and Aceh as well as interviews with Acehnese residents who still have relatives living in Kedah. after they settled in Yan, Langkawi, and several other areas, the involvement of the Acehnese people in community activities in the country of Kedah increased. The economy of the Acehnese people is also able to develop if they cultivate agricultural land, commerce, ownership of assets. In the political aspect too, solidarity and high patriotic enthusiasm and the great success of Acehnese figures in the social, economic, and political fields explain the role that has been cast in the history of the country of Kedah. At the end of the day, the assimilation and the fostering of a spirit of integration among the local community took effect. A concrete example of the results of the Aceh-Malaysia diaspora according to SERAMBI (2019) is the presence of the Masa cooperative which stands for Malaysia Aceh Solidaritas Agama.

This cooperative is predicted to become an umbrella for the Aceh popular shops that have spread to all corners of the country. This cooperative is predicted to become an umbrella for the popular Aceh shop that has spread to all corners of the country. 
The establishment of this cooperative has been approved by the Malaysian Cooperative Suruhanjaya (Commission). The real manifestation of the initial steps for the establishment of this cooperative has been started with the inauguration of the cooperation between the Kingdom of Malaysia and Acehnese traders, by the Minister of Agriculture and Industry Asas Tani Malaysia, Dato 'Salahuddin bin Ayub with the former Chairman of the Malaysian Government Advisory Board, Tun Daim Zainuddin, at Paya Jeras Hilir, Sungai Buloh, Selangor, Sunday (30/6/2019).

This cooperation includes the distribution of fish and cheap necessities through the Aceh chain of small shops to Malaysians. The main objective of this cooperation is to shorten the distribution range of fish and staple foods, aka to eliminate the role of intermediaries so that the fish sold to residents is fresher at a lower price than before. In line with the problems that occur, Aceh itself can mingle and adapt in Malaysia.

\section{Aspects of Acculturation Aceh - Malaysia Culture}

The concept of acculturation which is the basis of this research is the acculturation concept of Redfield, Linton, and Herskovits (1936: 149) which is elaborated with the acculturation concept of Berry (1997). The concept of acculturation Redfield, Linton, and Herskovits namely, Acculturation comprehends these phenomena which result when groups of individuals having different cultures come into continuous first-hand contact, with subsequent changes in the original cultural pattern of either or both group. " That acculturation is a phenomenon that occurs when several groups of people with different cultures make direct contact, then one or both of these groups experience a change in their original cultural pattern.

According to Datuk Muhammad Feisol bin Hassan (2013), The presence of the Acehnese people to Malaysia had taken place before Malaysia achieved its independence. At that time, immigrants from Aceh settled in the country of Kedah. Historically, there is a special relationship between Aceh and Kedah and to this day many Acehnese residents are living in Kedah. The presence of Acehnese immigrants to Malaysia at first was to avoid the conflicts and wars that occurred in Aceh at that time, then they settled in Malaysia and some have even become Malaysian citizens. 
Currently, the most important aspect of why the acculturation of Aceh and Malaysian culture is influenced by religious and economic aspects. Aceh which is famous for its Islamic sharia and individuals who have a strong merchant spirit facilitate the acculturation process of the Aceh community in Malaysia.

According to Miksalmina Budiman, quoted from Serambi (2014), the other values that are still familiar with them are polite words and adab peujamee (welcoming guests). The use of pure language, which can be said to be less common among the people of Aceh, who inhabit Indatu's land, but it looks like the daily practice of the people of Yan, Kedah, for example, pasai (cause), meucheen (miss), cut (small), gata (your call to glorify the younger), and others. Likewise in the case of peujamee, the way of welcoming it makes us feel as if we are in Aceh.

On the other hand, they are not only loyal to their heritage, but they are also loyal to the State of birth. Many of them have contributed services to the State of Malaysia, and as happy as they have been awarded the titles of Dato 'and Tan Sri. For example, the late Tan Sri P. Ramlee, an artistic figure who is proud of all Malaysian society, is still remembered today.

Another example, Tan Sri Dato 'Seri Haji Sanusi Bin Junid, he is the closest person to Dr. Mahathir (former prime minister of Malaysia), he was also used as Minister for Great Keudah. Until now he is a respected person, both by opponents and friends in politics. And many other figures have become milestones for the belief in the Malaysian State as we see today.

\section{Acehnese immigrant businesses to build a Kedai Runcit Business Network for Aceh - Malaysia Social Relations}

Kedai Runcit Aceh has become a new trend with the support of the Malays and Muslims who are more fond of merchandise sold by Malay and Islamic traders than others. Muslim Malays outside the city in particular prefer to shop at Muslim / Islamic Malay shops even if they are a few cents expensive than shopping at nonIslamic shops. This trend has been going on for a long time in Malaysian Malay society. 
The sales at the Aceh shop were not as perfect as the 7-eleven stalls which were beautifully arranged from various imported goods. Kedai Aceh is more about daily needs than fish, vegetables, fruits, often bananas and pineapples, so stop for other daily necessities such as Indian and Chinese shops which dominate the economic market in Malaysia.

The atmosphere inside the Aceh tavern feels very simple with the arrangement of the barangan still out of date, using old fashion timbers that are arranged not also following daily needs such as those at Tesco or Giant.

The impression of political polemic in Malaysia and coupled with the increasing awareness of Islam in Malaysia, Aceh taverns have become the choice to buy daily retail items, even if not all items are sold. If you want to compare the prices of goods at Kedai Aceh, it is more or less the same as other shops; That is why in Malaysia the sale of retail goods is subject to the law of the Ministry of User and Trade Affairs and is closely guarded by the ministry. The retail price of goods may not be sold arbitrarily according to the seller's wishes.

The price of fish at the Aceh shop is the same as the usual level at other fish shops. The fish are bought directly from acquaintances or catchers at the landing fish jets at the port and some are taken directly from the nearby Borong market. The Aceh tavern was also recognized as barangan from Indonesia, specifically those that were used daily by the Indonesian people and could be found here. The market may be that people who have just set foot on Malaysian soil can let go of homesickness for Indonesian items that are often used in their hometowns and maybe also for those who are not familiar with Malaysian-made food. sold at Kedai Aceh.

Various items of medicinal and herbal medicine in Aceh stalls brought in specially made in Indonesia are not much different from the herbal medicine seller in Chow Kit, Kuala Lumpur, which is controlled by the average Indonesian people from Padang, from the appearance of the products so that they are impressed by their use. You don't have to bother to go to Chow Kit if you want to look for medicines and herbs made in Indonesia, just at the Aceh shop.

Another thing that is a trend in Aceh shops apart from Indonesian branded medicines is coconut. Even though in Malaysia people prefer to buy packaged coconut milk, there are still many people who like to buy a shredded coconut at Aceh 
stalls for cooking, especially during the fasting month. Maybe the coconut milk is fresher or the dishes are tastier and tastier than what they are packaged.

Also, an important innovation in Aceh's unique shops and nowhere else is another innovation in money transfer services to Indonesia. Money transfers may be made at selected Aceh shops. This way of sending money is very unique, like in Western Union or Money gram. Within minutes the money sent was received by the family in Indonesia. The problem is if the money sent is large, you can no longer use this method of sending, you are forced to use the services of local banks.

In the past, the Aceh shop was famous for selling cigarettes made in Indonesia. For smokers from Indonesia who are not familiar with Malaysian-made or imported cigarettes, they prefer to get original Indonesian label cigarettes in Aceh shops. At present, it is said that it is quite difficult to get cigarettes in Aceh shops, almost vanishing sales of cigarettes made in Indonesia in Aceh stalls. Perhaps the Malaysian royal police reduce the distribution of imported cigarettes from outside, to provide quality health to the Malaysian people. On the other hand, the sales of Nipah leaf cigarettes / rolled cigarettes and tobacco are again increasing in Aceh shops. (channel73.com).

Following an interview with Encik Erfendi bin Alamsyah, a respondent who has been trading in Chow Kit, he explained that: "A trader must know and understand the concept of commercial ethics in Islam because as a Muslim, he should understand the commercial ethics in Islam. According to him the characteristics of trade ethics in Islam such as prioritizing honesty, trustworthiness, keeping promises, not committing fraud and not practicing usury in trade and exercising justice in trade management, selling at the same price to all buyers, giving appropriate salaries to workers. "

Encik Bustami bin Muhammad Daud also explained the same explanation: "Every salesperson must know ethics in trading so that this trade can be beneficial. Ethical matters that must be known are mandates such as being honest, do not cheat, and if the weighing items must be weighed correctly, and if the item is damaged, you must be told, do not hide, one more case, this trade should not be concerned with only yourself, and don't disappoint customers, because commerce is not for profit solely. And another thing, don't take things that don't belong to us, because that includes usury, that's what I know. " 
From the respondent's acknowledgment and explanation, it can be understood that ethics Commerce is very important in their commerce because it is a rule that every merchant should learn. Besides, Encik Erfendi bin Alamsyah and Encik Bustami bin Muhammad Daud also explained that, factors what makes his business success is due to consistency and responsibility answer and the hard work he does, never feeling bored inside trying to increase its commercial progress with enthusiasm, also always pray to Allah SWT. He also always puts values first kindness, trust, and honesty with customers who buy goods at the shop ensure fairness to all parties, maintain the quality of goods, and maintain satisfactory service to all customers.

\section{Conclusion}

From the discussion, we can conclude that the underlying reason why the Aceh and Malaysian diaspora occurs is due to the desire of the Acehnese people to get out of the threatening conflict zone and the strong life of the Acehnese community traders. Then the religious aspects also affect so that it is easy for the Acehnese people to adapt to Malaysia and be able to survive and unite the cultures of Aceh and Malaysia. One proof of this is that the Acehnese people can place themselves in politics in Malaysia and the well-known commerce in Seminyak, namely Runcit Shops. The presence of Runcit Shops itself gets a positive impression from Malaysian officials and can even work together for the diaspora process itself. 


\section{References}

Abubakar, Bustami. 2015. Sejarah dan Pola Migrasi Masyarakat Aceh ke Yan Kedah. Adabiya, 17 (33). pp. 70-87. ISSN 1411-6588

Erfendi bin Alamsyah (Peniaga Aceh di Wilayah Persekutuan Kuala Lumpur) Temu bual dengan penulis, 6 September 2013.

https://aceh.tribunnews.com/2019/07/18/catatan-dari-malaysia-koperasi-masadatuk-mansyur-hingga-kisah-tiga-diaspora-aceh-beda-generasi Artikel ini telah tayang di serambinews.com dengan judul Ada Kampung Aceh di Malaysia, https://aceh.tribunnews.com/2014/06/26/ada-kampung-acehdi-malaysia Editor: bakri

https://www.kanal73.com/news/kedai-aceh-di-malaysia-sebuah-ikon-dagangetnis-melayu/index.html

Missbach, Antje. 2011. Diaspora Aceh setelah Nota Kesepahaman Helsinki: tantangan balik dan transformasi pascakonflik diaspora, Asian Ethnicity.

Utusan Harian Online, Masyarakat Aceh Bantu Mangsa Banjir Malaysia ,Arkib: 26/11/2010,http://www.utusan.com.my/utusan/info.asp?y=2010\&dt=112 $6 \&$ pub=Utusan_Malaysia\&sec=Dalam_Negeri\&pg=dn_20.htm 